A N ARISTOCRACY OF CRITICS 


\section{THE COMMISSION ON FREEDOM OF THE PRESS}

ROBERT M. HUTCHINS, Chairman

Chancellor, The University of Chicago

ZECHARIAH CHAFEE, JR., Vice-Chairman

Professor of Law, Harvard University

JOHN M. CLARK

Professor of Economics, Columbia University

JOHN DICKINSON

Professor of Law, University of Pennsylvania, and General Counsel, Pennsylvania Railroad

WILLIAM E. HOCKING

Professor of Philosophy, Emeritus, Harvard University

HAROLD D. LASSWELL

Professor of Law, Yale University

ARCHIBALD MACLEISH

Formerly Assistant Secretary of State

CHARLES E. MERRIAM

Professor of Political Science, Emeritus, The University of Chicago

\section{REINHOLD NIEBUHR \\ Professor of Ethics and Philosophy of Religion, Union Theological Seminary \\ ROBERT REDFIELD \\ Professor of Anthropology, The University of Chicago \\ BEARDSLEY RUML \\ Chairman, Federal Reserve Bank of New York}

ARTHUR M. SCHLESINGER

Professor of History, Harvard University

GEORGE N. SHUSTER

President, Hunter College

FOREIGN ADVISERS

JOHN GRIERSON

Former General Manager, Wartime Information Board, Canada

${ }^{*} \mathrm{HU} \mathrm{SHIH}$

Former Chinese Ambassador to the United States

\author{
TJACQUES MARITAIN \\ President, Free French School for \\ Advanced Studies

\section{KURT RIEZLER} \\ Professor of Philosophy, New \\ School for Social Research
}

\section{STAFF OF THE COMMISSION \\ ROBERT D. LEIGH, Director \\ LLEWELLYN WHITE, Assistant Director \\ RUTH A. INGLIS \\ MILTON D. STEWART}

* Dr. Hu Shih was unable to participate in the work of the Commission after 1944.

† M. Maritain resigned February, 1945, to become French ambassador to the Holy See. 


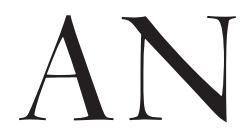

\section{ARISTOCRACY}

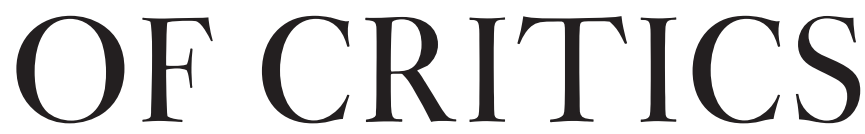

Luce, Hutchins, Niebuhr, and the Committee

That Redefined Freedom of the Press

\section{STEPHEN BATES}

\section{Yale}

UNIVERSITY PRESS

New Haven and London 
Published with assistance from the foundation established in memory of

Philip Hamilton McMillan of the Class of 1894 , Yale College.

Copyright $(\odot 2020$ by Stephen Bates.

All rights reserved.

This book may not be reproduced, in whole or in part, including illustrations, in any form (beyond that copying permitted by Sections 107 and Io8 of the

U.S. Copyright Law and except by reviewers for the public press), without written permission from the publishers.

Yale University Press books may be purchased in quantity for educational, business, or promotional use. For information, please e-mail sales.press@ yale.edu (U.S. office) or sales@yaleup.co.uk (U.K. office).

Set in Janson type by IDS Infotech, Ltd.

Printed in the United States of America.

Library of Congress Control Number: 2020935082

ISBN 978-0-300-I I I 89-7 (hardcover : alk. paper)

Frontispiece: A Free and Responsible Press (1947). (From A Free and Responsible Press, by the Commission on Freedom of the Press, edited by Robert D. Leigh; ( I 947 by The University of Chicago; reproduced by permission)

Excerpts from Time Inc. staff documents (C) I944, I945, I946, I947, I948, I949, I952, I964, I 968 by TI Gotham, Inc. All rights reserved. Reprinted/ translated and published with permission of TI Gotham Inc. Reproduction in any manner in any language in whole or in part without written permission is prohibited.

Some material in this book appeared in different form in the following: Stephen Bates, "Is This the Best Philosophy Can Do? Henry R. Luce and A Free and Responsible Press," Fournalism \& Mass Communication Quarterly 95, no. 3 (2018): 8 I I-834. Copyright 201 7, Association for Education in Journalism and Mass Communications. DOI: IO.I I 77/10776990I 7719873.

Stephen Bates, "Prejudice and the Press Critics: Colonel Robert McCormick's Assault on the Hutchins Commission," American fournalism 36, no. 3 (Fall 2019): 420-446.

A catalogue record for this book is available from the British Library.

This paper meets the requirements of ANSI/NISO Z $39 \cdot 48$-I992

(Permanence of Paper). 
To Clara and Charlotte 
This page intentionally left blank 